\title{
PRODUCTION OF FUNCTIONAL BIO - YOGHURT MADE FROM CAMEL MILK, SKIM MILK RETENTATE AND FORTIFIED WITH SWEET POTATO POWDER
}

\author{
Omar, H. H.; AMAL M.M. EL-NIMER; \\ M.A. Ahmed and H.M.H. HASSAAN \\ Dairy Technology Department, Animal Production Research Institute, \\ Agricultural Research Center, Giza, Egypt. \\ Corresponding author: amal_elnemr @yahoo.com.
}

(Manuscript received 10 January 2019)

\begin{abstract}
$\mathrm{T}$ he goal of this study was done to estimate the effect of partially replacement of camel's milk with skim milk retentate (SMR) as well as fortification with sweet potato powder (SPP) on the physicochemical, rheological, microbiological, microstructure and sensory properties of the resultant bio- yoghurt, during the storage. Yoghurt was made from camel milk as a control (C), and the other treatments were made from camel milk after replacing $30 \%$ or $40 \%$ of it by SMR, and fortified with $0,1.5$ and $3 \%$ SPP. Addition of (SM) aimed to overcome the problem of long coagulation time and the weak body arising by using camel milk. Results revealed that treatments of camel milk supplemented with (SMR) and (SPP) were more effective in increasing the total solids, protein, ash, total carbohydrates, acidity and total volatile fatty acid (TVFA). Curd firmness and syneresis were also affected, by the level of SMR and SPP. This fortification resulted in increasing the water holding capacity and lowering the susceptibility to syneresis in the supported yoghurt. Microbiological results revealed that the counts of L.delbruecii spp. bulgaricus, and S.thermophilus were increased up to 3 days of storage then decreased gradually thereafter, in all treatments till the end of the storage period, compared with control one. B.bifidum behaved another trend so it decreased gradually during the storage period. The survival rate of S.thermophills in treatments containing SMR and SPP was higher than that of both L. delbruecii spp. bulgaricus and $B$. bifidum. The viable cells of probiotic bacteria were maintained at the functional level $\left(>10^{6} \mathrm{cfu} / / \mathrm{ml}\right.$ ) up to 10 days of storage. Scanning electron microscopy showed that the size of casein clusters and protein aggregates, the number and size of voids were not the same between the different treatments and was affected by the additives used. Sensory attributes showed that addition of SMR and SPP to camel milk improved greatly both the organoleptic properties, especially body \& texture, the nutritive value and healthy benefits in the resultant yoghurt, compared to the control. The best treatment was yoghurt contained $40 \%$ SMR and 3\% SPP. Control yoghurt was the lowest one in scoring and had very weak body (semi- liquid) and lack of acid flavor.

Key words: Camel milk, Skim milk retentate, Sweet potato powder, Probiotic or bio- yoghurt.
\end{abstract}




\section{INTRODUCTION}

Camel (Camels dromedaries) is considerable socio-economic value in many arid and semi-arid areas of the world and its milk comprises a significant part of human dietary habits in these areas. Fresh and fermented camel milk have been used in different regions in the world including Africa and the Middle East for treatment several diseases. The positive health effect of milk proteins can be presented as anticarcinogenic, anti-diabetic (Agrawal et al., 2007) and has been recommended to be consumed by children who are allergic to bovine milk. The general chemical composition of camel milk varies in various part of the world with average range of 3.07- $5.50 \%$ fat, 3.5-4.5\% protein, $0.7-0.95 \%$ ash, 3.4-5.6\% lactose and $12.1-15 \%$ total solid. Camel milk contains more whey protein, lower casein content and a very low ratio of beta-CN to kappa-CN than in cow milk (Kappeler et al., 1998). All these factors influence the technological properties of the heat treatment and acid or enzymatic coagulation of camel's milk (so it is almost semi liquid). Camel milk is high in vitamins ( $A, B_{2}, C$ and $E$ ) and minerals (sodium, potassium, iron, copper, zinc and magnesium) and lower in cholesterol (Al- Hashem, 2009). Camel's milk is different from other ruminant milk and it does not form proper coagulum in acidic environment. Thus, fermented camel milk products are difficult to produce because of the problem in milk coagulation (due to the low percent of a - s casein). Agrawal et al., (2007) found that camel milk coagulum failed to reach a gel-like structure with lactic acid culture even after $18 \mathrm{~h}$ incubation, because it contains a greater amounts of whey protein and antimicrobial components such as lysozyme, lactoferrin and immunoglobulin's than bovine or buffalo milk.

Yoghurt is defined as the coagulated product obtained from pasteurized milks (whole, skim, concentrated, boiled) by lactic acid fermentation through the action of yoghurt starter; Lactobacillus bulgaricus and Streptococcus thermophilus which produce lactic acid not less than $0.85 \%$ and not more than $1.2 \%$.. It is one of the most popular fermented milk products, and optimum consistency and stability to syneresis is of primary concern to the dairy industry.

Therefore, one of the most important step in the production of camel yoghurts is the increase of its total solids content by the addition of skim milk powder or sodium caseinate or milk retentate to optimize the viscosity and improve the body and texture.

The use of ultrafiltration (UF) technique for adjusts total solids of camel milk for the production of fermented dairy products has been reported (Schkoda et al., 2001). Milk concentrated (retentate) by UF has been shown to produce a good quality yoghurt (smooth, creamy body with typical acid flavor) without needs to homogenization, so it 
increased viscosity, improve both curd firmness and the nutritional value owing to the higher protein, calcium and phosphorus contents in the final product. On the other hand, yoghurt produced from camel milk (without any additives) was reported to have a thin and very weak texture due to its low of a - s casein (Hashim et al., 2009). Recently, some researchers attempt to reduce syneresis and improve the texture by increasing the total solids of camel milk, using milk retentate (Mortada and Omer, 2013) or sweet potato powder.

Sweet potato is a good food for people involved in heavy muscular work, since it contains high levels of carbohydrates which make up $90 \%$ of dry matter ( the major carbohydrate components is starch, being 60-70\% amylopectin and 30-40\% amylose, beta-carotene, vitamins $\left(A, B_{6}, C\right.$ and $E$ ) and minerals (potassium, phosphorus, manganese, and zinc) which have several health benefits . It contains, also, powerful antioxidants which remove the free radicals from the body (these free radicals are harm chemicals that damage cells), fiber and pectin which are useful in preventing digestive disorders such as hemorrhoids, constipation, and fighting colon cancer. Sweet potatoes are rich in carbohydrates and poor in protein. So, potatoes are the most efficient fuel for energy production and can also be stored as glycogen in muscle and liver, functioning as a readily available energy source for prolonged strenuous exercise, Suryia-Zakir et al., (2008).

Therefore, the aim of this study was to produce bio-yoghurt from whole camel milk after partially replacement part of this milk with milk retentate ( to overcome the problem of long acid coagulation time and very weak body, noticed during the production of that yoghurt), beside fortification the resultant milk by sweet potato powder (a nutritive and healthy functional ingredient) and studying the action of this replacement and fortification on the chemical, microbiological, rheological, microstructure and sensory properties of the resultant product, during cold storage.

\section{MATERIALS AND METHODS}

\section{Materials:}

Fresh whole camel milk was obtained from the herd of Camel Research Center, Marsa Matrough. Skim milk retentate was obtained from the Dairy Processing Unit, Animal production Research Institute and Sweet potato roots were obtained from the local market.

Lyophylized strains of Streptococcus thermophilus St. 36, Lactobacillus delbrueckii subsp bulgaricus Lb. 12, and Bifidobacterium bifidum Bb.11 were obtained from Chr. Hansen Lab. Copenhagen, Denmark. Each strain was sub-culturing several times on its appropriate medium and mixed at a level of (1:1:1) just before use. The 
chemical composition of fresh camel milk, skim milk retentate (SMR) and sweet potato powder (SPP) was shown in Table (1).

Table 1. Chemical composition of fresh camel milk, skim milk retentate and Sweet potato Powder.

\begin{tabular}{|c|c|c|c|}
\hline Components (\%) & Camel milk & $\begin{array}{l}\text { Skim milk } \\
\text { retentate }\end{array}$ & Sweet Potato powder \\
\hline Total Solids & 12.64 & 20.0 & 91.64 \\
\hline Protein & 3.23 & 12.34 & 2.87 \\
\hline Fat & 4.20 & 0.85 & 0.76 \\
\hline Ash & 0.84 & 1.83 & 2.19 \\
\hline Total Carbohydrate* & 4.37 & 4.98 & 82.80 \\
\hline Fiber & --- & ---- & 3.02 \\
\hline
\end{tabular}

*Calculated by difference

\section{MATERIALS AND METHODS}

\section{Preparation of Sweet Potato Powder:}

Sweet potato roots were rinsed in tap water, manually peeled, thinly sliced into a 2$\mathrm{mm}$ thickness, blanched in water at $90-95^{\circ} \mathrm{C}$ for $1 \mathrm{~min}$, dried at $60^{\circ} \mathrm{C}$ for $5-8 \mathrm{~h}$, ground, and sieved through an 80- mesh sieve to produce uniform-size powder Collado and Corke, (1996). The powder was packaged in polypropylene bags and stored at $5 \pm 1{ }^{\circ} \mathrm{C}$ until used.

\section{Manufacture of yoghurt:}

Probiotic fermented camel's milk was manufactured according to the method reported by Tamime and Robinson, (1999). Several preliminary trials were done by partially replacing part of the whole camel milk with 10, 20, 30, 40 and $50 \%$. Skim milk retentate to choose the best suitable one for producing good quality yoghurt. Firmness, body $\&$ texture, acid coagulation time and sensory properties were used for that 10 and $20 \%$ supplementation resulted in unacceptable yoghurt, while 30 and 40 $\%$ were found the best. On the other hand, using $50 \%$ ratio caused some texture problems. Another preliminary trials were done on sweet potato powder using 1.5, 3, $4,6,8,10$ and $12 \%$, results showed that the best ones were 1.5 and $3 \%$ (good structure and less synersis), whereas increasing the ratios above that causing some problems in both body \& texture and appearance .

\section{Treatments were carried out as follows:}

Whole camel milk as a control, without SMR or SPP.

Whole camel milk was replaced with 30\% SMR, without SPP.

Whole camel milk was replaced with $30 \%$ SMR, fortified with $1.5 \%(w / v)$ SPP.

Whole camel milk was replaced with $30 \%$ SMR, fortified with $3 \%(w / v)$ SPP.

Whole camel milk was replaced with $40 \%$ SMR without SPP.

Whole camel milk was replaced with $40 \%$ SMR, fortified with $1.5 \%$ (w/v) SPP.

Whole camel milk was replaced with $40 \%$ SMR, fortified with3 \% (w/v) SPP. 
Milk of all treatments were heat- treated at $65^{\circ} \mathrm{C}$ for $30 \mathrm{~min}$., cooled to $43^{\circ} \mathrm{C}$, inoculated with $3 \%(\mathrm{w} / \mathrm{v})$ mixed culture $(1: 1: 1)$, packaged in plastic cups (50 gm. ) and incubated at $42^{\circ} \mathrm{C}$ until complete coagulation. Samples were kept in refrigerator at $5 \pm 1{ }^{\circ} \mathrm{C}$, for 10 days, then analyzed after $1,3,7$ and 10 days of storage for physicochemical, rheological , microbiological, microstructure and sensory properties. This experiment was repeated 3 times.

\section{METHODS OF ANALYSIS}

\section{Physico -chemical characteristics}

Total solids, protein, fat, ash, dietary fiber and titratable acidity of whole camel milk, skim milk retentate or probiotic yoghurt samples (A.O.A.C., 2007). pH values were determined using $\mathrm{pH}$ meter, Consort P400, Scientific instrument S/N 55/25, made in Belgum. Total volatile free fatty acids Kosikowski, (1982). Carbohydrate content Ceirwyn, (1995), using the following formula:

Total carbohydrates $\%=100-$ (\%fat $+\%$ protein $+\%$ ash $+\%$ fiber $+\%$ moisture $)$.

\section{Rheological analysis:}

Curd tension (firmness) Shalabi, (1987). Syneresis (whey separation) Marshall, (1982).

\section{Microbiological analysis:}

Total bacterial count and S.thermophilus, counted on M17 agar (Oxiod Ltd) and incubated at $37^{\circ} \mathrm{C}$ for $48-72 \mathrm{~h}$ (Torriani et al., 1996). L. delbrueckii subsp. bulgaricus was counted on MRS-agar medium (Dave and Shah, 1996). Bifidobacterium bifidum was anaerobically plated on MRS-NNLP medium, at $37^{\circ} \mathrm{C}$ for $72 \pm 1 \mathrm{~h}$ (Lankaputhra et al., 1996). Results were recorded as log number of colony forming units per gram (Log. cfu/g).

\section{Microstructure examination:}

The Electron microscopic analysis was performed in the Egyptian Mineral Resources Authority Central Laboratories Sector. The Scanning Electron microscope (SEM) for fresh camel's milk yoghurt samples was carried out using SEM (FEL Company, Nether lands). Model Quanta 250 FEG (Field Emission Gun) attached with EDX Unit (Emergy Dispersivex Ray Analysis), with accelerating Voltage $10 \mathrm{KV}$. During SEM Analysis, samples were freezer fractured in liquid nitrogen to approximately 1$\mathrm{mm}$ pieces and the pieces were then mounted on aluminum stubs with silver paint, dried to critical point and coated with gold for $300 \mathrm{Sm}$ sputter coater (SCD 005 Sputter Coater) and scanned under low vacuum conditions with pressure chambers 60 Pa. Karami et al., (2009). 


\section{Sensory evaluation:}

A number of 10 trained panelists from the staff members of Dairy Dept., Animal Production Research Institute, were organoleptically examined the samples, according to the scheme described by (Nelson and Trout 1981). The samples were organoleptically scored using the following score card: flavor (60 points), body and texture (30 points), appearance (10 points). Panelists scoring all yoghurt samples after storage for $1,3,7$, and 10 days at $5 \pm 1^{\circ} \mathrm{C}$.

\section{RESULTS AND DISCUSSION}

\section{Physico-chemical composition:}

It was clear that, the total solids, protein, fat and ash contents of all bioyoghurt samples gradually increased with increasing the storage period, while the total carbohydrate were behaved the opposite trend (Table 2). The results were in agreement with Hassan and Ismran, (2010) who referred that to the evaporation of water or loss of moisture content. Results revealed, also, that the total solids and protein contents were increased as the percentage of sweet potato or skim milk retentate increased. Protein content of fresh bio-yoghurt ranged from 5.96 to $6.96 \%$ compared with $3.23 \%$ of control treatment. Variations in the protein contents could be attributed to the differences in the level of sweet potato powder or skim milk retentate used. Fat content of control yoghurt was higher along the storage period than the other treatments. Results were similar to those found by Bozanie and Tratnik., (2001) who found that addition of different milk protein concentrates to UF yoghurt, decreased the rate of syneresis and increased the protein content in the resultant yoghurt. Total carbohydrates of the fresh bio-yoghurt contained skim milk retentate and sweet potato powder ranged from 4.05 to 6.59 . The higher percentage of carbohydrates noticed in treated yoghurt reterned to the higher percentage of carbohydrate in the sweet potato powder used. 
Table 2. Effect of fortifying camel milk with sweet potato powder on chemical composition of bio- yoghurt made from camel milk with partially replacement by skim milk retentate, during the storage period.

\begin{tabular}{|c|c|c|c|c|}
\hline \multirow{2}{*}{ Treatments } & \multicolumn{4}{|c|}{ Period of Storage (days) } \\
\hline & 1 & 3 & 7 & 10 \\
\hline \multicolumn{5}{|c|}{ Total Solids \% } \\
\hline Control (C) & 12.62 & 12.65 & 12.71 & 12.75 \\
\hline $\mathrm{T}_{1}$ & 14.55 & 14.59 & 15.00 & 15.05 \\
\hline $\mathrm{T}_{2}$ & 15.87 & 15.93 & 16.14 & 16.23 \\
\hline $\mathrm{T}_{3}$ & 17.21 & 17.25 & 17.30 & 17.32 \\
\hline $\mathrm{T}_{4}$ & 15.18 & 15.42 & 15.44 & 15.47 \\
\hline$T_{5}$ & 16.60 & 16.71 & 16.73 & 16.74 \\
\hline $\mathrm{T}_{6}$ & 17.86 & 18.04 & 18.05 & 18.07 \\
\hline \multicolumn{5}{|c|}{ Total Protein \% } \\
\hline Control (C) & 3.23 & 3.25 & 3.28 & 3.3 \\
\hline $\mathrm{T}_{1}$ & 5.96 & 5.98 & 6.09 & 6.16 \\
\hline $\mathrm{T}_{2}$ & 6.00 & 6.04 & 6.15 & 6.18 \\
\hline $\mathrm{T}_{3}$ & 6.02 & 6.16 & 6.22 & 6.28 \\
\hline $\mathrm{T}_{4}$ & 6.88 & 7.01 & 7.08 & 7.14 \\
\hline$T_{5}$ & 6.92 & 7.03 & 7.14 & 7.18 \\
\hline $\mathrm{T}_{6}$ & 6.96 & 7.09 & 7.18 & 7.29 \\
\hline \multicolumn{5}{|c|}{ Total Fat $\%$} \\
\hline Control (C) & 4.19 & 4.32 & 4.45 & 4.53 \\
\hline $\mathrm{T}_{1}$ & 3.40 & 3.57 & 4.08 & 4.14 \\
\hline $\mathrm{T}_{2}$ & 3.44 & 3.58 & 4.09 & 4.15 \\
\hline $\mathrm{T}_{3}$ & 3.49 & 3.59 & 4.10 & 4.18 \\
\hline $\mathrm{T}_{4}$ & 3.15 & 3.20 & 3.27 & 3.32 \\
\hline $\mathrm{T}_{5}$ & 3.26 & 3.28 & 3.31 & 3.38 \\
\hline $\mathrm{T}_{6}$ & 3.32 & 3.36 & 3.39 & 3.44 \\
\hline \multicolumn{5}{|c|}{ Total Carbohydrate\% } \\
\hline Control (C) & 4.35 & 4.19 & 4.05 & 3.96 \\
\hline $\mathrm{T}_{1}$ & 4.05 & 3.88 & 3.65 & 3.55 \\
\hline $\mathrm{T}_{2}$ & 5.29 & 5.12 & 4.76 & 4.68 \\
\hline $\mathrm{T}_{3}$ & 6.53 & 6.21 & 5.72 & 5.56 \\
\hline $\mathrm{T}_{4}$ & 4.11 & 3.96 & 3.82 & 3.72 \\
\hline$T_{5}$ & 5.35 & 5.20 & 4.99 & 4.86 \\
\hline $\mathrm{T}_{6}$ & 6.59 & 6.40 & 6.18 & 5.99 \\
\hline \multicolumn{5}{|c|}{ Ash \% } \\
\hline Control (C) & 0.85 & 0.89 & 0.93 & 0.96 \\
\hline $\mathrm{T}_{1}$ & 1.14 & 1.16 & 1.18 & 1.20 \\
\hline $\mathrm{T}_{2}$ & 1.17 & 1.19 & 1.21 & 1.23 \\
\hline$T_{3}$ & 1.24 & 1.27 & 1.28 & 1.30 \\
\hline $\mathrm{T}_{4}$ & 1.24 & 1.25 & 1.27 & 1.29 \\
\hline$T_{5}$ & 1.27 & 1.27 & 1.29 & 1.32 \\
\hline $\mathrm{T}_{6}$ & 1.31 & 1.32 & 1.33 & 1.35 \\
\hline
\end{tabular}

Whole camel milk as a control, without SMR or SPP.

Whole camel milk was replaced with 30\% SMR, without SPP.

Whole camel milk was replaced with $30 \%$ SMR, fortified with $1.5 \%$ (w/v) SPP. ..........( $\left(T_{2}\right)$

Whole camel milk was replaced with $30 \%$ SMR, fortified with $3 \%(w / v)$ SPP. ....... $\quad\left(T_{3}\right)$

Whole camel milk was replaced with $40 \%$ SMR without SPP.

Whole camel milk was replaced with $40 \%$ SMR, fortified with $1.5 \%$ (w/v) SPP....

Whole camel milk was replaced with $40 \%$ SMR, fortified with3 \% (w/v) SPP. 
Results in Table, (3) indicated that titratable acidity (TA) of the control yoghurt had the lowest value during storage, whereas T6 (containing $40 \%$ SMR and $3 \%$ SPP) recorded the highest values. TA of all treatments were increased as the level of both SMR and SPP. increased. TA values of control treatment ranged between $0.73-0.85 \%$ and the corresponding values of the other treatments were $0.82-1.17 \%$, during the storage period. TA of all treatments increased gradually as the storage period advanced. $\mathrm{pH}$ values of all treatments behaved reverse trend to TA, during storage. The higher values of TA in treatments containing SPP, compared to the other ones and control, may be due to the presence of some growth factors in SPP which enhancing and increasing the starter activity. Similar results were obtained by Bozanic and Tratnik, (2001) for both probiotic yoghurt and fermented bifido milk. Data in Table (3) revealed, moreover, that total volatile fatty acids (TVFA) values were gradually increased in all bio-yoghurt samples with extending the storage period. The rate of increase in TVFA was found higher in all treatments than in control. It was observed that when the ratio of SPP added increased, the values of TVFA decreased. T3 had the highest values at the end of the storage period.

Table 3. Effect of fortifying camel milk with sweet potato powder on titratable acidity, $\mathrm{pH}$ values and total volatile fatty acids** of bio- yoghurt made from camel milk with partially replacement by skim milk retentate, during the storage period .

\begin{tabular}{|c|c|c|c|c|}
\hline Treatments* & $\begin{array}{c}\text { Storage } \\
\text { period (days) }\end{array}$ & TVFA & $\begin{array}{c}\text { pH } \\
\text { values }\end{array}$ & $\begin{array}{c}\text { Titratable } \\
\text { Acidity }\end{array}$ \\
\hline \multirow{4}{*}{ Control (C) } & 1 & 6.7 & 4.85 & 0.73 \\
\hline & 3 & 6.9 & 4.76 & 0.79 \\
\hline & 7 & 7.4 & 4.73 & 0.82 \\
\hline & 10 & 7.9 & 4.69 & 0.85 \\
\hline \multirow{4}{*}{$\mathrm{T}_{1}$} & 1 & 8.2 & 4.81 & 0.82 \\
\hline & 3 & 8.7 & 4.62 & 0.93 \\
\hline & 7 & 11.6 & 4.57 & 0.96 \\
\hline & 10 & 14.3 & 4.52 & 1.08 \\
\hline \multirow{4}{*}{$\mathrm{T}_{2}$} & 1 & 8.4 & 4.77 & 0.84 \\
\hline & 3 & 8.9 & 4.61 & 0.95 \\
\hline & 7 & 11.9 & 4.55 & 0.99 \\
\hline & 10 & 14.7 & 4.51 & 1.10 \\
\hline \multirow{4}{*}{$T_{3}$} & 1 & 8.5 & 4.64 & 0.87 \\
\hline & 3 & 9.1 & 4.60 & 0.96 \\
\hline & 7 & 12.0 & 4.53 & 1.02 \\
\hline & 10 & 14.9 & 4.50 & 1.13 \\
\hline \multirow{4}{*}{$\mathrm{T}_{4}$} & 1 & 7.4 & 4.63 & 0.87 \\
\hline & 3 & 8.1 & 4.56 & 0.98 \\
\hline & 7 & 10.7 & 4.54 & 1.03 \\
\hline & 10 & 13.4 & 4.51 & 1.12 \\
\hline \multirow{4}{*}{$T_{5}$} & 1 & 7.7 & 4.61 & 0.89 \\
\hline & 3 & 8.3 & 4.60 & 0.99 \\
\hline & 7 & 10.9 & 4.58 & 1.07 \\
\hline & 10 & 13.5 & 4.50 & 1.12 \\
\hline \multirow{4}{*}{$T_{6}$} & 1 & 7.9 & 4.59 & 0.91 \\
\hline & 3 & 8.5 & 4.56 & 1.02 \\
\hline & 7 & 11.3 & 4.52 & 1.13 \\
\hline & 10 & 13.7 & 4.49 & 1.17 \\
\hline
\end{tabular}

4.49

1.17 


\section{Rheological Properties:}

Data shown in Table (4) revealed that fermentation process of the control yoghurt required very long time (approximately $18 \mathrm{~h}$ ) because camel milk contains more whey protein, lower casein content and low ratio of beta-CN to kappa-CN than in cow milk (Kappeler et al., 1998). The other treatments containing SMR coagulated faster (273 -320 min.), and a reverse relationship between the rate of SMR added and the acid coagulation time was found. Values of curd syneresis, of all treatments, were gradually decreased during the storage period as the percentage of milk retentate and sweet potato powder increased. Syneresis and curd firmness of the control treatment $(C)$, were not detected owing to its very weak body and texture. Addition of SMR greatly improved the curd firmness and minimized the rate of syneresis. A negatives relationship was found between the rate of SMR or SPP used and the values of curd firmness and syneresis, along the storage period. Similar results were reported by Akalin et al., (2012) who observed that increasing the total solid in milk caused an increase in the density, reduced the pore size in the protein matrix of the yoghurt gel, lead to a reduction in the syneresis and improved the water holding capacity of the yoghurt gel. Our results showed, moreover, that the higher values of curd firmness were noticed in T6, while the lowest one was in T1. Values of syneresis were opposite to values of curd firmness.

Table 4. Coagulation time (min.), curd firmness (g) and curd syneresis $(\mathrm{ml} / 25 \mathrm{ml})$ of bio- yoghurt made from camel milk partially replacement with skim milk retentate, as affected by fortification with sweet potato powder, during the storage.

\begin{tabular}{|c|c|c|c|c|}
\hline Treatments* & $\begin{array}{l}\text { Storage period } \\
\text { (day) }\end{array}$ & $\begin{array}{l}\text { Milk Coagulation } \\
\text { Time (min.) }\end{array}$ & $\begin{array}{l}\text { Curd } \\
\text { Firmness (g) }\end{array}$ & $\begin{array}{l}\text { Curd Syneresis } \\
(\mathrm{ml} / 25 \mathrm{ml})\end{array}$ \\
\hline \multirow{4}{*}{ Control (C) } & 1 & 1080 & $\mathrm{Nd}$ & nd \\
\hline & 3 & --- & $\mathrm{Nd}$ & nd \\
\hline & 7 & ---- & $\mathrm{Nd}$ & nd \\
\hline & 10 & --- & $\mathrm{Nd}$ & nd \\
\hline \multirow{4}{*}{$\mathrm{T}_{1}$} & 1 & 320 & 58.2 & 14.2 \\
\hline & 3 & --- & 59.0 & 13.1 \\
\hline & 7 & ---- & 59.4 & 11.9 \\
\hline & 10 & --- & 59.7 & 11.5 \\
\hline \multirow{4}{*}{$T_{2}$} & 1 & 312 & 72.5 & 10.9 \\
\hline & 3 & --- & 73.3 & 10.4 \\
\hline & 7 & --- & 73.9 & 10.2 \\
\hline & 10 & --- & 74.2 & 10.1 \\
\hline \multirow{4}{*}{$T_{3}$} & 1 & 303 & 78.4 & 10.5 \\
\hline & 3 & ---- & 79.2 & 10.4 \\
\hline & 7 & $\begin{array}{l}--- \\
\end{array}$ & 79.8 & 10.3 \\
\hline & 10 & ---- & 80.2 & 10.1 \\
\hline \multirow{4}{*}{$\mathrm{T}_{4}$} & 1 & 286 & 64.5 & 12.3 \\
\hline & 3 & ---- & 65.4 & 11.4 \\
\hline & 7 & --- & 65.8 & 10.8 \\
\hline & 10 & --- & 66.2 & 10.5 \\
\hline \multirow{4}{*}{$T_{5}$} & 1 & 280 & 75.6 & 9.2 \\
\hline & 3 & ---- & 76.4 & 8.8 \\
\hline & 7 & ---- & 77.0 & 8.3 \\
\hline & 10 & ---- & 77.4 & 7.9 \\
\hline \multirow{4}{*}{$\mathrm{T}_{6}$} & 1 & 273 & 80.4 & 8.7 \\
\hline & 3 & ------ & 81.3 & 8.5 \\
\hline & 7 & ----- & 81.8 & 8.1 \\
\hline & 10 & ------ & 82.1 & 7.7 \\
\hline
\end{tabular}




\section{Microbiological properties:}

Results in Table (5) indicated that, the total viable bacterial count (TC) in all treatments was low at the beginning of the storage period owing to the presence of growth inhibiting factors, especially lysozyme, in camel milk. TC and probiotic bacterial counts in the treatments containing SMR or SPP were higher than the corresponding ones of control yoghurt, along the storage period. It increased up to 3 days (with the exception of bifidobacteria) then decreased gradually, in all strains, till the end of the storage period. The main reason for that may be due to the continuous increase in acidity. Akalin et al. (2007) stated that decreasing the number of counts during storage may be due to the death of the viable flora of the sample and refer that to a number of factors including: $\mathrm{H} 2 \mathrm{O} 2$ produced by the starter bacteria, oxygen content, $\mathrm{pH}$ value, storage environment and concentration of metabolites such as lactic acid

Data in Table (5), moreover, revealed that the counts of the starter culture ( $S$. thermopiles; L. delbruecii spp. bulgaricus and B. bifidum) were apparently higher than the similar ones of control yoghurt. The most prevalent strains, in all treatments, either when fresh or during storage, were $S$. thermophiles followed by L.delbruecii spp. bulgaricus and B.bifidum, in order.The survival rate (\%), among all treatments, ranged between 80.67 - 95.08 and the highest one (95.08) was found in T6 for $S$. thermophiles (contained 40\% SMR and 3\% SPP) whereas the lowest one $(80.67 \%)$ was noticed in control treatment for Bifidobacteria. Counts of Bifidobacteria were higher in all treatments than the beneficial recommended count ( $>10^{6} \mathrm{cfu} / \mathrm{g}$ ) mentioned by Marafon, et al., ( 2011).

It was noticed, generally, that as the level of SMR or SPP increased the counts of all strains of the starter culture increased. Treatment 6 (contained $40 \%$ SMR or $3 \%$ SPP) recorded the highest counts and control one recorded the lowest ones. Survival rate of bifidobacteria was high being $81.24 \%$ in control and $85.82 \%$ in T6. Counts of all treatments were decreased gradually as the storage period advanced. 
Table 5. Effect of adding sweet potato powder on the microbiological properties (Log $\mathrm{CFu} / \mathrm{g}$ ) of probiotic yoghurt made from whole camel milk partially replacement with skim milk retentate, during the storage.

\begin{tabular}{|c|c|c|c|c|c|c|c|}
\hline \multirow{2}{*}{$\begin{array}{c}\begin{array}{c}\text { Storage period } \\
\text { (days) }\end{array} \\
\end{array}$} & \multicolumn{7}{|c|}{ Treatments* } \\
\hline & C & $\mathrm{T} 1$ & $\mathrm{~T} 2$ & T3 & T4 & T5 & T6 \\
\hline \multicolumn{8}{|c|}{ Total viable bacterial Count } \\
\hline 1 & 6.34 & 7.08 & 7.23 & 7.13 & 7.14 & 7.34 & 7.33 \\
\hline 3 & 6.39 & 7.10 & 7.29 & 7.19 & 7.22 & 7.31 & 7.38 \\
\hline 7 & 5.71 & 6.97 & 7.11 & 7.01 & 7.06 & 7.19 & 7.26 \\
\hline 10 & 5.23 & 6.55 & 7.72 & 6.65 & 6.64 & 6.87 & 6.88 \\
\hline Survival rate $\%$ & 82.49 & 92.51 & 92.83 & 93.21 & 93.00 & 93.62 & 93.93 \\
\hline \multicolumn{8}{|c|}{ L. delbrueckii SSp.bulgaricu } \\
\hline 1 & 7.57 & 8.54 & 8.74 & 8.65 & 8.70 & 8.85 & 8.89 \\
\hline 3 & 7.61 & 8.58 & 8.79 & 8.72 & 8.76 & 8.91 & 6.91 \\
\hline 7 & 7.36 & 8.19 & 8.33 & 8.42 & 8.49 & 8.47 & 8.55 \\
\hline 10 & 6.41 & 7.80 & 8.03 & 7.99 & 8.11 & 8.31 & 8.35 \\
\hline Survival rate \% & 84.88 & 91.33 & 91.88 & 92.37 & 93.22 & 93.90 & 93.93 \\
\hline \multicolumn{8}{|c|}{ S. thermophilus } \\
\hline 1 & 7.47 & 8.53 & 8.71 & 8.83 & 8.91 & 8.85 & 8.94 \\
\hline 3 & 7.49 & 8.56 & 8.74 & 8.86 & 8.95 & 8.92 & 8.99 \\
\hline 7 & 7.37 & 8.32 & 8.47 & 8.60 & 8.72 & 8.76 & 8.82 \\
\hline 10 & 6.40 & 7.88 & 8.09 & 8.24 & 8.35 & 8.35 & 8.50 \\
\hline Survival rate \% & 85.68 & 92.41 & 92.92 & 93.32 & 93.71 & 94.35 & 95.08 \\
\hline \multicolumn{8}{|c|}{ Bifidobacterium bifidum } \\
\hline 1 & 7.50 & 7.65 & 7.85 & 7.73 & 7.80 & 8.17 & 8.39 \\
\hline 3 & 7.25 & 7.50 & 7.60 & 7.65 & 7.93 & 8.05 & 8.15 \\
\hline 7 & 6.80 & 7.25 & 7.42 & 7.48 & 7.69 & 7.62 & 7.77 \\
\hline 10 & 6.05 & 6.30 & 6.55 & 6.55 & 6.55 & 6.90 & 7.20 \\
\hline Survival rate $\%$ & 80.67 & 82.35 & 83.44 & 84.73 & 83.97 & 84.46 & 85.82 \\
\hline
\end{tabular}

*see foot note Table (2).

\section{Microstructure:}

Microstructure of fresh camel milk yoghurt of all treatments was studied by scanning electron microscope ( SEM) Figs. (1\&2). The yoghurt matrix was generally made up of protein network in which fat globules are embedded and voids ( black area ) occupied by the water phase. Protein form the major structural network of the yoghurt (appeared in the micrograph as a grey area ) and entrap the fat.

\section{Effect of skim milk retentate (SMR):}

The influence of SMR was quite clear, so it improved the microstructure of the resultant yoghurt to be homogeneous, showing the presence of small aggregates of casein micelles linked together with finer-meshed network Fig. $(1 \mathrm{~A})$. 
Increasing the rate of SMR up to $40 \%$ was prefer than $30 \%$, so the microstructure was characterized by large stretched of continuous protein matrix (PM) interspersed with serum channels Fig. (4D). Contrarily, this yoghurt had low numbers of both fat globules as well as small size voids. A Generally, it was reverse relationship was found between the percent of SMR added, and the number and size of voids or vacuoles.

\section{Effect of sweet potato powder (SPP):}

Addition of SPP led to form a complex-like gel with whey, owing to the thickening effect of SPP which contained high percent (44-78\%) of starch. This complex appeared in the micrograph under the name $(W+P)$. As the concentration of SPP increased the areas of $(W+P)$ were increased and the number of voids were decreased Figs. (2B, 3C, 5E and 6F).

Casein micelles (C) of yoghurt contained the high level ( $3 \%$ ) of SPP were linked continuously and strongly because of the thickening effect of starch. This may explain the increase in yoghurt hardness with increasing the concentration of SPP.

Generally, it was noticed that the size of casein clusters and protein aggregates, the number and size of voids were not the same between the different treatments and was affected by the additives used 

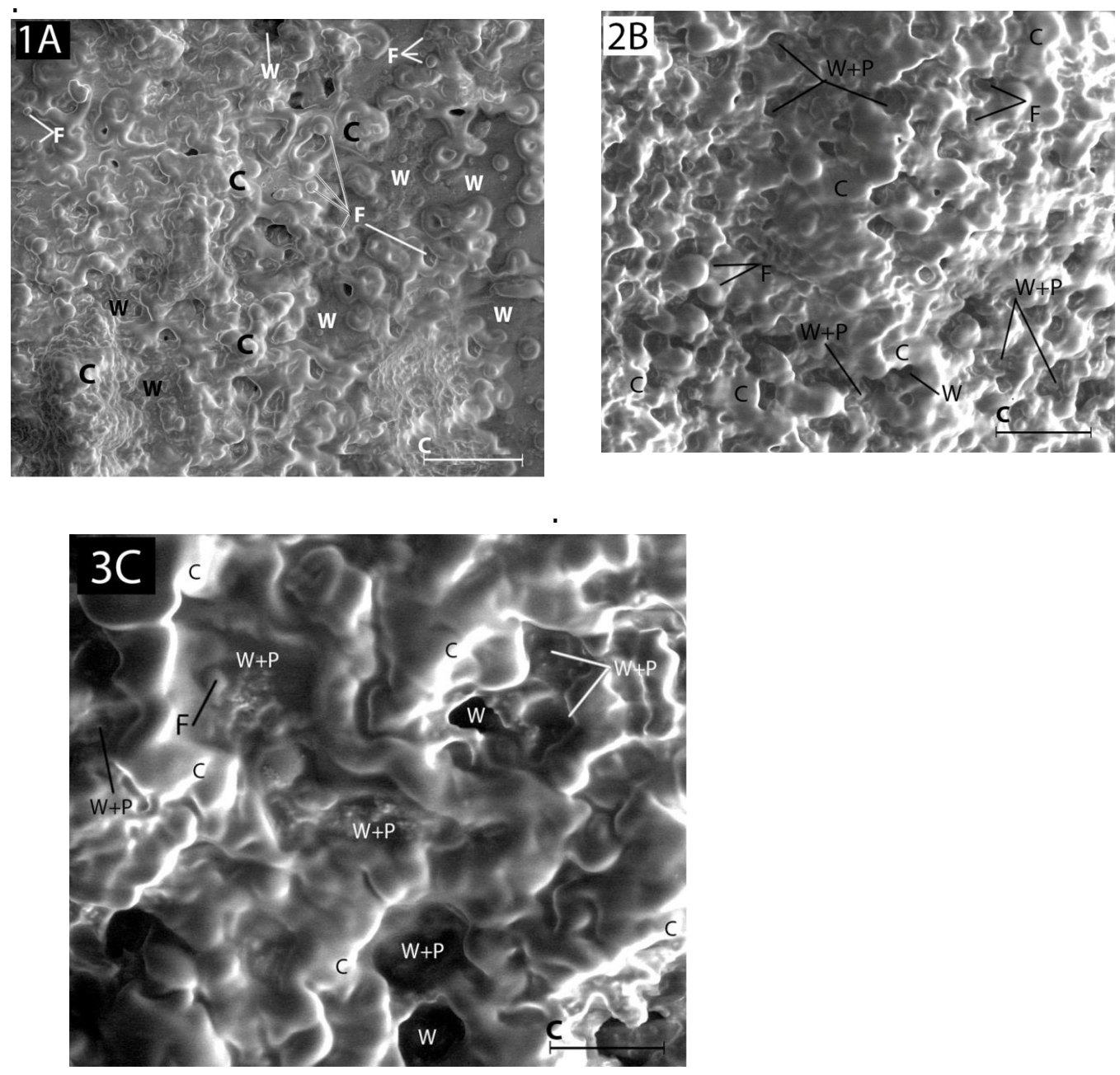

Fig. 1. SEM micrographs of fresh yoghurt made from whole camel milk, Retentate and fortified with sweet potato powder.

1 A: Made from $70 \%$ camel milk $+30 \%$ Retentate.

2 B: Made from $70 \%$ camel milk $+30 \%$ Retentate $+1.5 \%$ Sweet Potato powder

3 C: Made from $70 \%$ camel milk $+30 \%$ Retentate $+3 \%$ Sweet potato powder.

C: Casein ; W: Whey ; F : Fat globule ; CJ : Curd junction ; W+P : Whey + Sweet Potato powder .

Bar $=2.5 \mathrm{~nm}$ 


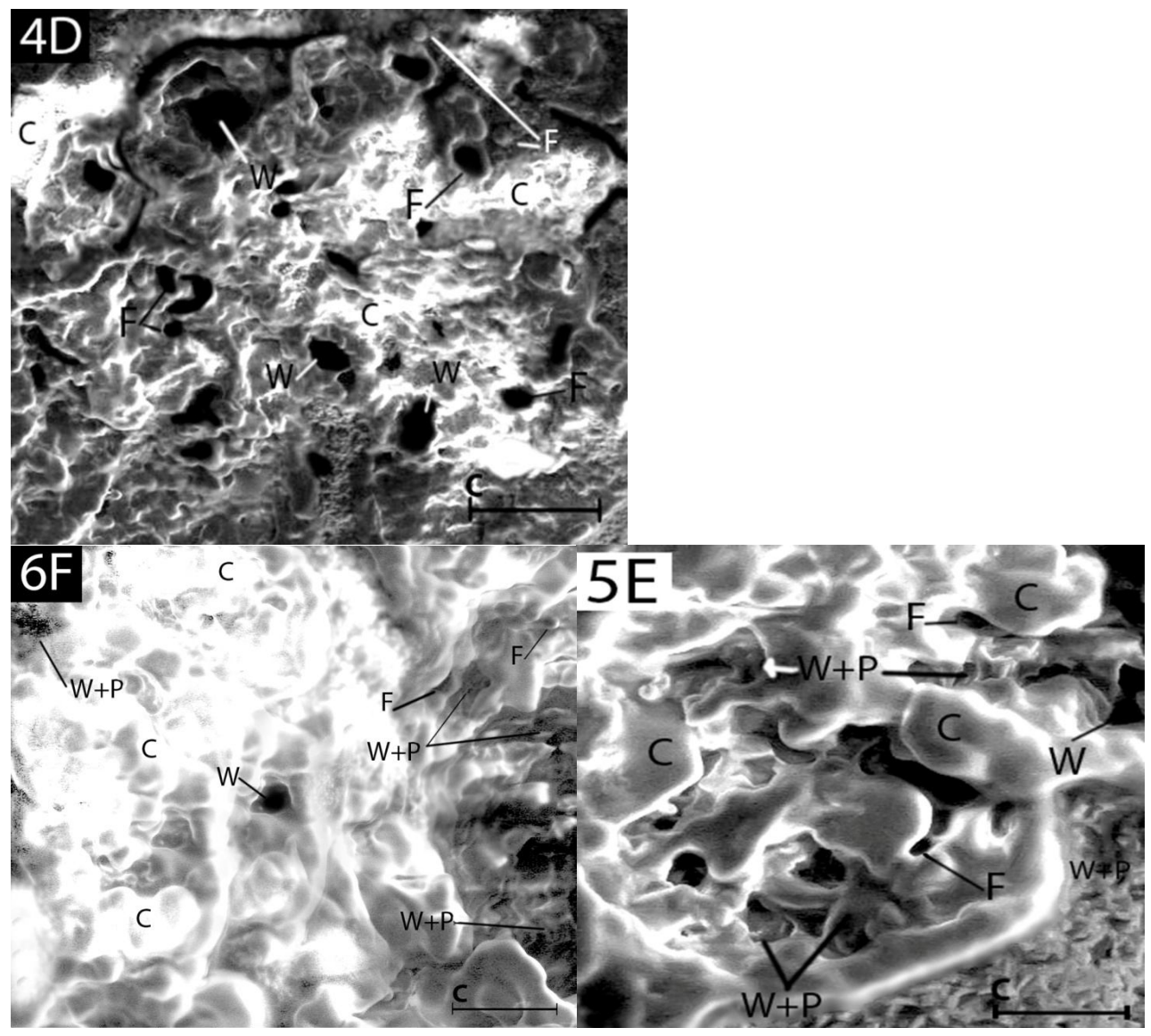

Fig. 2. SEM micrographs of fresh yoghurt made from whole camel milk, Retentate and fortified with sweet potato powder.

4D: made from $60 \%$ Camel milk $+40 \%$ Retentate.

5E: Made from $60 \%$ camel milk $+40 \%$ Retentate $+1.5 \%$ Sweet Potato powder.

6F: Made from $60 \%$ camel milk $+40 \%$ Retentate $+3 \%$ Sweet potato powder.

C: Casein - W: Whey- F : Fat globule - CJ : Curd junction - W+P : Whey + Sweet Potato powder.

Bar $=2.5 \mathrm{~nm}$.

\section{Sensory properties:}

Table (6) showed that the use of skim milk retentate (SMR), sweet potato powder (SPP) and probiotic starter increased greatly the sensory attributes of the resultant yoghurt, especially its flavor and body \& texture as compared with the control. These results are in agreement with Akalin et al.,(2012) who found that the metabolism of the probiotic culture can result in some of components that may contribute positively to the aroma of the product. Our results revealed, moreover, that control yoghurt had the lowest score points (30) owing its very weak body \& texture and inferior flavor. These result agreed with Abou-Soliman et al., (2017) who recorded that, camel milk produces watery, thin and very soft texture when processed yogurt. On the other hand, the use of SMR improved much the 
former attributes of yoghurt. Marafon et al., (2011) mentioned that, supplementing camel milk with milk protein resulted in an increase in the sensory attributes, especially consistency, of the resultant probiotic yoghurt. Results in Table (6), in addition, indicated that a positive relationship was found between the sensory properties of the yoghurt and the ingredients used. Treatment (6) had slightly the highest score points (83.6), along the storage period. Generally, the sensory properties of all treatments were gradually decreased as the storage period increased.

Table 6. Sensory evaluation of probiotic yoghurt made from whole camel milk replaced partially with SMR and fortified with SPP, during the storage.

\begin{tabular}{|c|c|c|c|c|}
\hline \multirow{2}{*}{ Treatments* } & \multicolumn{4}{|c|}{ Period of Storage (days) } \\
\hline & 1 & 3 & 7 & 10 \\
\hline \multicolumn{5}{|c|}{ Flavor (60) } \\
\hline Control(C) & 25 & 20 & 17 & 15 \\
\hline $\mathrm{T}_{1}$ & 50.9 & 50.7 & 50.5 & 49.8 \\
\hline $\mathrm{T}_{2}$ & 51.3 & 51.1 & 50.7 & 50.2 \\
\hline $\mathrm{T}_{3}$ & 52.9 & 51.8 & 51.2 & 50.4 \\
\hline $\mathrm{T}_{4}$ & 48.5 & 48.3 & 47.8 & 47.2 \\
\hline $\mathrm{T}_{5}$ & 49.6 & 48.4 & 48.0 & 47.5 \\
\hline $\mathrm{T}_{6}$ & 50.8 & 48.7 & 48.3 & 47.7 \\
\hline \multicolumn{5}{|c|}{ Body \& Texture (30) } \\
\hline Control(C) & 3 & 1.5 & 1 & 0 \\
\hline $\mathrm{T}_{1}$ & 22.4 & 22.4 & 22.2 & 21.8 \\
\hline $\mathrm{T}_{2}$ & 25.6 & 25.4 & 24.2 & 23.9 \\
\hline $\mathrm{T}_{3}$ & 26.2 & 26.1 & 26.0 & 25.2 \\
\hline $\mathrm{T}_{4}$ & 24.3 & 24.2 & 23.9 & 23.4 \\
\hline $\mathrm{T}_{5}$ & 27.0 & 26.8 & 26.5 & 26.0 \\
\hline $\mathrm{T}_{6}$ & 28.1 & 28.0 & 27.6 & 27.2 \\
\hline \multicolumn{5}{|c|}{ Appearance (10) } \\
\hline Control(C) & 2 & 2 & 1 & 1 \\
\hline $\mathrm{T}_{1}$ & 9.0 & 9.0 & 8.5 & 8.0 \\
\hline $\mathrm{T}_{2}$ & 9.0 & 9.0 & 8.5 & 8.0 \\
\hline $\mathrm{T}_{3}$ & 9.0 & 9.0 & 8.5 & 8.0 \\
\hline $\mathrm{T}_{4}$ & 9.0 & 9.0 & 8.5 & 8.0 \\
\hline $\mathrm{T}_{5}$ & 9.0 & 9.0 & 8.5 & 8.0 \\
\hline $\mathrm{T}_{6}$ & 9.0 & 9.0 & 8.5 & 8.0 \\
\hline \multicolumn{5}{|c|}{ Total Scores (100) } \\
\hline Control(C) & 30 & 23.5 & 19 & 16 \\
\hline $\mathrm{T}_{1}$ & 82.2 & 82.1 & 81.2 & 79.6 \\
\hline $\mathrm{T}_{2}$ & 85.9 & 85.5 & 83.4 & 82.1 \\
\hline $\mathrm{T}_{3}$ & 88.1 & 86.9 & 85.7 & 82.9 \\
\hline $\mathrm{T}_{4}$ & 81.8 & 81.5 & 80.2 & 78.6 \\
\hline $\mathrm{T}_{5}$ & 85.6 & 84.2 & 83.0 & 81.5 \\
\hline $\mathrm{T}_{6}$ & 87.9 & 85.7 & 84.4 & 83.6 \\
\hline
\end{tabular}

*see foot note Table (2). 


\section{CONCLUSION}

The use of skim milk retentate (SMR) was found more suitable to overcome the problem arising when manufactured yoghurt from whole camel milk. Camel milk yoghurt (without SMR) had watery, thin and very soft texture and lack of flavor. Fortification with sweet potato powder (SPP) (increase the water holding capacity, act as a thickening agent and had nutritive and healthy benefits), as well as using probiotic bacteria as a starter culture improved greatly the quality and the sensory attributes (especially body \& texture) of the resultant probiotic yoghurt. Addition of SMR and SPP improved greatly the microstructure (especially with the high percent's) of the resultant camel milk yoghurt. Counts of Bifidobacteria were higher in all treatments than the beneficial recommended count $\left(>10^{6} \mathrm{cfu} / \mathrm{g}\right.$ ). The natural antimicrobial compounds present in camel milk might increase its shelf life, and make it superior than any other yoghurt, health benefits.

\section{REFERENCES}

1. Akalin, A. S., Gone, S. and Fenderya, S. 2007. Effects of fructo-oligo saccharides and whey protein concentrate on the viability of starter culture in reduced fat probiot yoghurt during storage . J. of Food Sci, 72: $222-227$.

2. A.O.A.C. 2007. Association of Official Analytical Chemists, Official Methods of Analysis, Vol. $118^{\text {th }}$ ed. Washington, D.C.

3. Abou-Soliman, N.H.I., Sakr, S.S. and Awad, S. 2017. Physico-chemical, microstructure and heological properties of camel-milk yogurt as enhanced by microbial transglutaminase. J. F. Food Technol., 54(6) 1616-1627.

4. Agrawal, R. P., Budania, S., Sharma, P., Gupta, R., and Kochar, D. K. 2007. Zeroprevalence of diabetes in camel milk consuming Raica. Community of north-west Rajasthan, India. Diabetes Research and Clinical Practice, 76, 290-296.

5. Akalin, A. S., Unal, G., Dinkci, N. and Hayaloglu, A. A. (2012). Microstructure, textural and sensory characteristics of prebiotic Yogurts fortified with sodium calcium caseinate or whey protein concentrate. J.Dairy Sci., 95(7), 3617-3628.

6. Al-Hashem, F. 2009. Camel milk protects against aluminum chloride-induce toxicity in the liver and kidney of white albino rats. Am.J. Biochem. Biotechnology.., 5, 98-108.

7. Bozanic, R. and Tratnik, L. J. 2001. Quality of Cow's and Goat's fermented bifido milk during storage. Food Technology and Biotechnology, 39, 109-114.

8. Ceirwyn S.J. 1995. Analytical Chemistry of Foods. Part I Pub.Blackie Academic a professional P.135.

9. Collado, L.S., and Corke H. 1996. Use of wheat-sweet potato com-posite flours in yellowalkaline and white-salted noodles. Cereal Chem. 73, 439 - 444.

10. Dave R.I. and Shah, N.P. 1996. Evaluation of media for selective enumeration of Streptococcus thermophillus, Lactobacillus delbrueckiisub sp. Bulgaricus, Lactobacillus a acidophilus and bifidobacteria. J. Dairy Sci., 79, 1529-1536. 
11. Hashim, I.B., Khalil, A.H. and Habib, H. 2009. Quality and acceptability of a set-type yoghurt mad from camel milk. J.Dairy Sci., 92, 857-862.

12. Hassan, A. and Ismran, A. 2010. Nutritional evaluation of yoghurt prepared by different starter cultures and their physiochemical analysis during storage.J.Biotech,9, 2913- 2917.

13. Kappeler, S., Farah, Z. and Puhan, Z. 1998. Sequence analysis of camelus dromedaries milk caseins. J. Dairy Res., 65, 209-222.

14. Karami, M., Ehsani, U.R., Mousavi, SM., Rezaei, k. and Safari, M. 2009. Changes in the rheological properties of Iranian UF. Feta cheese during ripening. Food Chem., 112: 539.

15. Kosikowski, F. 1982. Cheese and fermented milk foods. Second Edition, Published by F.V. Kosikowski and Associates, New York.

16. Lankaputhra, W.E.V.,Shah, N.P. and Britz, M. L. 1996. Evaluation of media for selective enumeration of Lactobacillus acidophilus and Bifidobacterium SPP. Food Australia, 48, 113 $-118$.

17. Marafon, A. P., Sumi, A., Granato, D., Alcântara, M. R., Tamime, A.Y. and Oliveira,M.N. 2011. Effects of partially replacing skimmed milk powder with dairy ingredients on rheology, sensory profiling, and microstructure of probiotic stirred-type yogurt during cold storage. J. Dairy Sci., 94, 5330-5339.

18. Marshall R. G. 1982. An improved method for measurement of the synersis of curd formed by rennet action on milk. J.Dairy Res.49: 329 - 336.

19. Mortada, M. S. and Omer, I. A. H. 2013. Effect of fortifying camel's milk with Skim milk powder on the physicochemical, microbiological and sensory characteristics of set yoghurt.

Advance Journal of Food Science and Technology, 5(6), 765-770.

20. Nelson J.A. and Trout G. M. 1981. Judging of Dairy Products.4 th ED. AVI Publishing Company, INC. Westport Connection, PP. 295-313.

21. Schkoda, O., Hechler, A.and Hinrichs, J. 2001. Influence of the protein content on structural characteristics, of stirred fermented milk. Milchwissenschaft, 56,19-22.

22. Shalabi S.I. 1987. Milk clotting activity of cmmercial rennet Substitutes. Acomparitive Study. Menia J.Agric. Res.Dev.9: 441- 460.

23. Surayia-Zakir, Mohmmad, S., Allen, J., Butt,M.S., Mehr,U.N., Umair,A., Islam. U.D. and Asif-javaid. 2008. Impact of Sweet Potato Cultivars on blood glucose level in diabetic and healthy Participants. International J. of Agriculture and Biology 2008, 10 (3): 316 320 .

24. Tamime, A.Y. and Robinson, R.K. 1999. Yoghurt. Science and Technology.Cambridge, UK: Woodhead Publishing Limited England.

25. Torriani, S., Gardini, F., Guerzoni, M.E. and Dellaglio, F. 1996. Use of response surface methodology to evaluate some variable affecting the growth and acidefication characteristics of yoghurt cultures. Int. Dairy J., 6, 625-636. 


\title{
أنتاج اليوجورت الحيوى المصنع من لبن الأبل و مركز اللبن الفرز والمدعم بمسحوق البطاطا
}

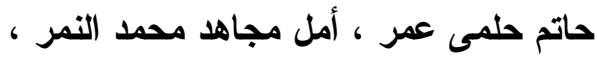 \\ محمد على أحمد ، حسن محمد حسن حسان \\ قسم بحوث تكنولوجيا الألبان بمعهد بحوث الأنتاج الحيوانى
}

تهدف هذه الدراسة الى تحسين خواص اليوجورت الحيوى المصنع من لبن الجمال و التغلب

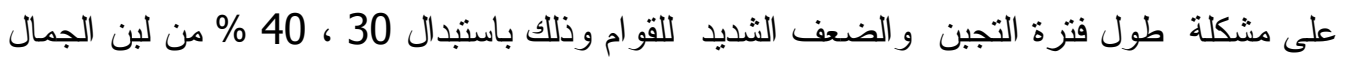
بمركز اللبن الفرز ( المنتج بطريقة UF ) وتدعيم اللبن الناتج بمسحوق البطاطا الحلوة بنسية 1.5 ، 3\% ودراسة تاثير ذلك على الخواص الفيزوكيمائية ، الريولوجية ، الميكروبيولوجية ، خصائص التصن

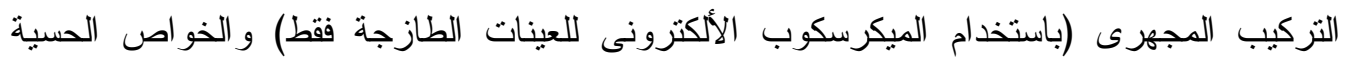
خلا فترات التخزين على 5 × 10 م مقارنة بالكنترول المصنع من لبن الجمال فقط و وأظهرت النتائج مايلى:-

- تدعيم لبن الجمال بمركز اللبن الفرز ومسحوق البطاطا الحلوة أدى الى زيادة المواد الصلبة

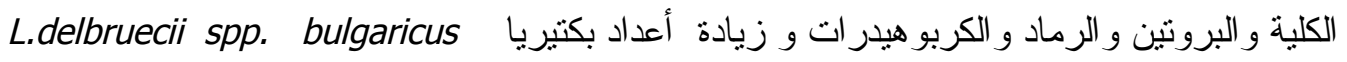
مدة S. theremophills.

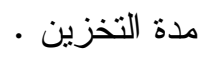

- ت تدريجيا حتى نهاية مدة التخزين وظلت بالنسبة المرغوبة اى اكثر من مليون خلية / الجر ام.

- أوضحت النتائج أن زيادة نسبة التدعيم بمركز اللبن الفرز الى نسبة 40\% ومسحوق البطاطا الحلوة الى 3\% أدى لزيادة الصلابة فى الخثرة وقلة المنرشح من الثرش و وانخفاض في زمن زمن التجبن

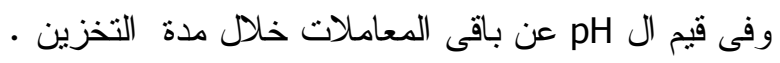

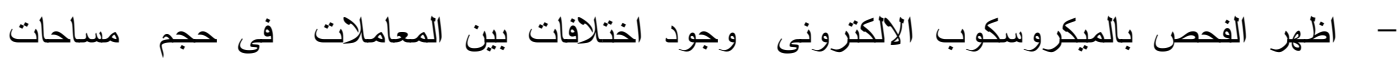

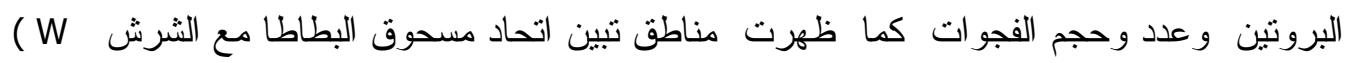

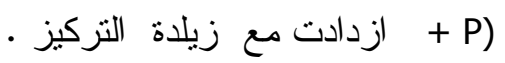

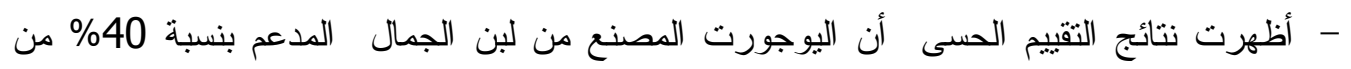

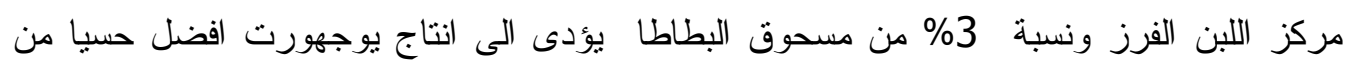

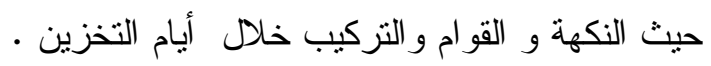

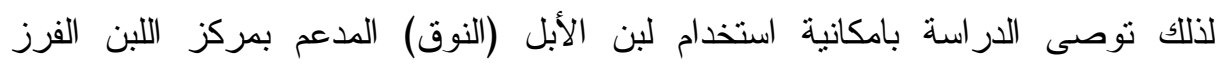
ومسحوق البطاطا الحلوة والبادئ الحيوى فى انتاج منتج لبنى حيوى متخمر اقتصادى ، ذو صفات حسية جيدة و فو ائد غذائية وصحية عديدة عائ 